Génét. Sél. Evol., 1986, 18 (4), 375-384

\title{
Pig gene mapping: assignment of the genes for mannosephosphate isomerase (MPI) and nucleoside phosphorylase (NP) to chromosome no. 7
}

\author{
G. DOLF and G. STRANZINGER
}

Federal Institute of Technology, Institute of Animal Sciences, CH-8092 Zürich, Switzerland

\begin{abstract}
Summary
Ten hybrid cell lines (pig $\times$ a3 Chinese hamster) have been investigated with respect to their content of pig chromosomes and the enzymes MPI and NP. The pig chromosomes have been identified by their Q-band pattern. The enzymes were analysed by cellulose acetate gel electrophoresis. The results indicate that the genes for MPI and NP are located on chromosome no. 7.
\end{abstract} $(N P)$.

Key words : Pig, gene mapping, mannosephosphate isomerase (MPI), nucleoside phosphorylase

\section{Résumé}

Carte génique du porc: assignation des gènes de la mannosephosphate isomérase (MPI) et de la nucléoside phosphorylase (NP) au chromosome $n^{\circ} 7$

La présence de chromosomes porcins et des enzymes MPI et NP a été recherchée dans $\mathbf{1 0}$ lignées de cellules hybrides (porc $\times$ a3 hamster chinois). Les chromosomes porcins ont été identifiés grâce à leurs bandes $\mathrm{Q}$ caractéristiques et les enzymes analysés par électrophorèse sur gel d'acétate de cellulose. Les résultats indiquent que les gènes codant pour MPI et NP sont situés sur le chromosome $\mathbf{n}^{\circ} 7$. $(N P)$.

Mots clés : Porc, carte génique, mannosephosphate isomérase (MPI), nucléoside phosphorylase

\section{Introduction}

The present state of the pig gene map includes roughly 40 genes. Most of them belong to linkage groups, whereas only a few genes have been assigned directly to a chromosome. The genes for HPRT, G6PD, PGK and GLA have been located on the

Reprint request : Prof. Dr. G. Stranzinger. 
X-chromosome by means of somatic cell hybrids (Foerster et al., 1980 ; Gellin et al., 1980 ; LeONG et al., 1983a). The diseases "splayleg " (LAX, 1971) and "tremor AIII" (HARDING et al., 1973) are also associated with the X-chromosome. Autosomal assignments were made by the methods of family analysis, in situ hybridization and mostly somatic cell hybridization. The gene for the $G$ blood group has been assigned to chromosome no. 15 by family studies (Fries, 1982; TikHonov \& Nikitin, 1983 ; TikHonov et al., 1983 ; Fries et al., 1984). This implies that the linkage group GPIHAL-S-H-PO2-PGD could also be located on chromosome no. 15, as a close linkage between the loci for the $G$ and the $H$ blood groups (TikHonov et al., 1983) and a weak linkage between the locus for GPI and the centromere of chromosome no. 15 (FrIEs et al., 1982) have been found. By in situ hybridization the loci for the SLA could be assigned to chromosome no. 7 (GefrRotin et al., 1984 ; RABIN et al., 1985 ; EchARD et al., 1986). Therefore the linkage group C-J (MuIR \& RASMuSEN, 1974) is likely to be located on the same chromosome, since a close linkage has been found between the loci for the blood group J and the SLA (Hruban et al., 1976). The following genes have been assigned by the approach of somatic cell hybridization. The syntenic group MPI-NP-PKM2 (Gellin et al., 1981) has been located on chromosome no. 3 (EchaRD et al., $1982 ; 1984)$ and the gene for SOD1 on chromosome no. 9 (LEONG et al., 1983b). FoERSTER \& Hecht (1984) assigned the genes for MDH1 to chromosome no. 3, for LDHA to chromosome no. 4, for LDHB to chromosome no. 5, for PEPB to chromosome no. 11, for PGM1 to chromosome no. 10 and for ME1 to chromosome no. 1 or no. 17. Further they confirmed the assignment of the gene for SOD1 to chromosome no. 9. However, they found the loci for MPI and NP to be on chromosome no. 7, which is in contrast to the assignment by ECHARD et al. (1984).

In the following we present our own findings. They confirm the assignment of the genes for MPI and NP to chromosome no. 7 as also do the results of Christensen et al. (1985).

\section{Materials and methods}

\section{A. Hybrid cell lines}

Cells of the a3 Chinese hamster cell line (WESTERveld et al., 1971) were fused with pig fibroblasts in one experiment and pig leucocytes in 2 other experiments. The cell suspension was then distributed to petri dishes $\left(10^{5}\right.$ cells/petri dish). The clones were selected in HAT medium (hypoxanthine $8.8 \times 10^{-5} \mathrm{M}$, aminopterine $4 \times 10^{-7} \mathrm{M}$, thymidine $\left.3.3 \times 10^{-5} \mathrm{M}\right)$, to which ouabain $\left(10^{-5} \mathrm{M}\right)$ was added in the case where pig fibroblasts were involved. Between 9 and 18 days after the fusion the clones were isolated. Per petri dish one single clone, that had no other clones in its neighbourhood, was chosen. By adding one drop of 0.25 p. 100 trypsine solution, a chosen clone was detached and with a pasteur pipette transferred to a small culture flask. After isolation the hybrid cell lines were kept in Ham's F10 medium, supplemented with 10 p. 100 fetal calf serum. The procedures of hybridization, selection and isolation used in this investigation have already been described in detail (Dolf \& STranzinger, 1982 ; Dolf, 1984).

The 10 hybrid cell lines investigated resulted from 3 independent fusion experiments. In 5 hybrid cell lines the donor cells were pig fibroblasts and in the other 2 and 3 , respectively, they were pig leucocytes. 
The hybrid lines were kept deep frozen when they were not under investigation. At any time no more than 5 hybrid lines were investigated. Cell preparations for both chromosome and enzyme analysis were made out of the same culture flask at the same passage, but not at the very same time. Therefore the procedure was repeated for each hybrid cell line.

\section{B. Chromosome analysis}

The cultures were visually checked several times a day in order to establish the moment when the number of dividing cells was the greatest. The dividing cells were harvested by adding Dispase $(0.8 \mathrm{U} / \mathrm{ml})$ to the culture and gently shaking the flask. The resulting cell suspension was centrifuged for $10 \mathrm{~min}$ at $450 \times \mathrm{g}$. The cell pellet was resuspended in a $\mathrm{KCl}$ solution $(0.071 \mathrm{M})$ and incubated at $37^{\circ} \mathrm{C}$ for $20 \mathrm{~min}$. After 10 min of centrifugation at $450 \times g$, fixative (methanol : acetic acid $3: 1$ ) was added to the pellet. The fixation was repeated twice. Slides were prepared the following day. The metaphase chromosomes were Q-banded according to the procedure by CASPERSson et al. (1969) and identified according to the Reading Conference (1976) in the case of pig chromosomes and RAY \& MoHANDAS (1976) in the case of hamster chromosomes.

\section{Enzyme analysis}

The preparation of the cell lysates and the electrophoresis on cellulose acetate gels were carried out as described by MeERA KHAN (1971) and VAN SOMEREN et al. (1974). The following enzymes were investigated :

\begin{tabular}{|c|c|c|}
\hline Glucosephosphate isomerase & EC 5.3.1.9 & (GPI) \\
\hline Lactate dehydrogenase & EC 1.1.1.27 & (LDH) \\
\hline Mannosephosphate isomerase & EC 5.3.1.8 & (MPI) \\
\hline Nucleoside phosphorylase & EC 2.4.2.1 & (NP) \\
\hline
\end{tabular}

\section{Results}

\section{A. Chromosome and enzyme analysis}

The pig chromosomes were identified within the metaphases without arranging them in karyotypes (fig. 1). On the average 40 metaphases were analysed per hybrid cell line. In most cases the metaphases were incomplete. As this loss of chromosomes is due to the influence of the chromosome preparation, that is physical factors, rather than biological factors, we assumed that it occurred randomly. Pig chromosomes were considered to be present in a hybrid cell line, when they could be found in at least 10 p. 100 of the investigated metaphases. The pig Y-chromosome has been omitted, as it is highly unlikely to harbor the genes of the investigated enzymes. Also it has not been found in this investigation. The observations concerning the pig chromosomes and the pig enzymes are summarized in table 1. As an example, a zymogram of NP is 


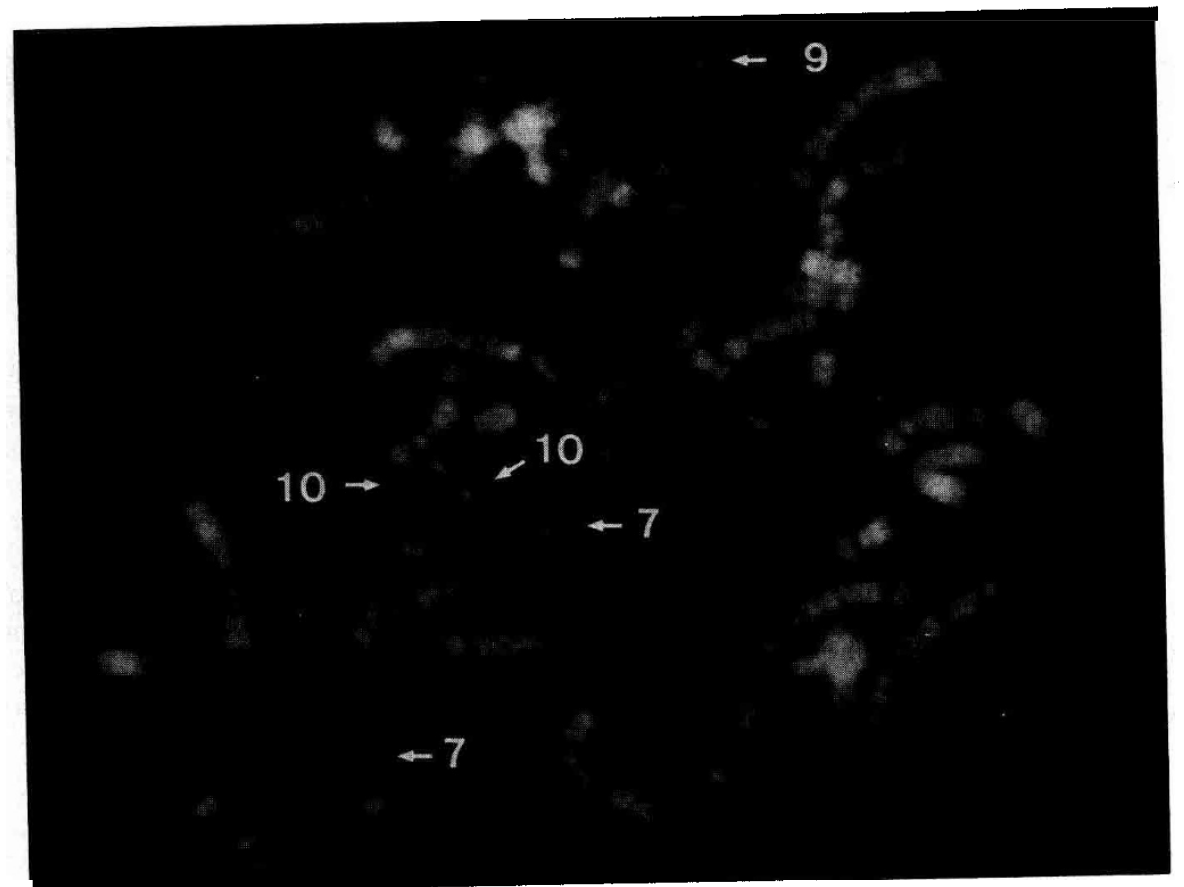

Fig. 1

Q-banded metaphase of hybrid line no. 7. The arrows point to pig chromosomes.

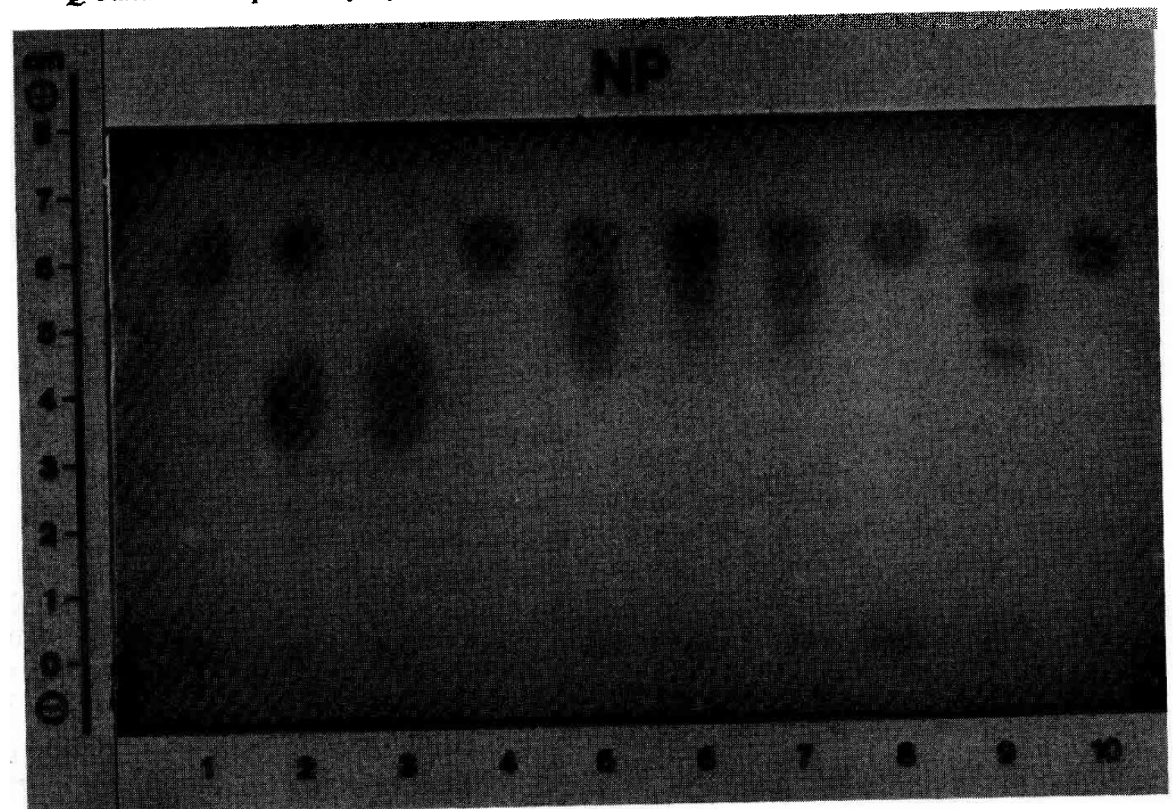

Fig. 2

Zymogram of NP: 1 hamster, 2 pig + hamster, 3 pig, $4-10$ hybrid lines : $5,6,7$ and 9 showing pig NP. 


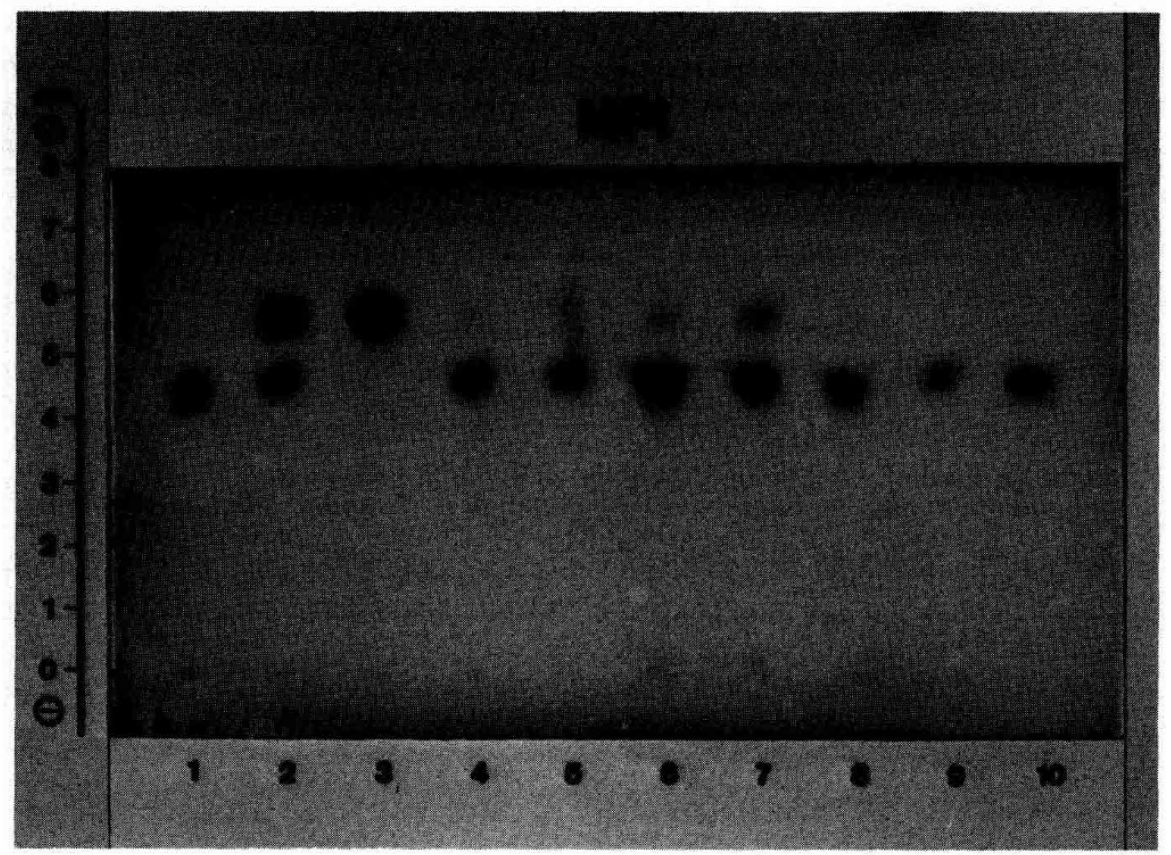

FIG. 3

Zymogram of MPI : 1 hamster, 2 pig + hamster, 3 pig, $4-10$ hybrid lines : 4 - 7 showing pig $M P I$.

shown in figure 2. As NP is a trimer, 2 intermediate bands can be observed in the cases where both the hamster and the pig NP are expressed. The hybrid lines that express the pig MPI show 2 bands as MPI is a monomer (fig. 3).

\section{B. Chromosomal assignments}

There are different approaches to the interpretation of data resulting from investigations in somatic cell hybrids with respect to gene mapping. In this investigation we chose 2 statistical procedures to treat our data (table 1). One procedure is based on the outcome of the values of Phi, Chisq and OR (Cowmeadow \& RuddLe, 1978) and the other on the outcome of the values of the likelihood ratios $R_{j}$ (DoLF, 1984). Our data did not allow us to assign the genes for GPI, LDH and PEPA. But it was possible to assign the genes for MPI and NP to chromosome no. 7. In this investigation MPI and NP were perfectly syntenic. The values of Phi, Chisq, OR and $R_{j}$ were calculated for each pig chromosome except the Y-chromosome (table 2). 
TABLE 1

The occurrence of pig chromosomes (p. 100) and pig enzymes in the investigated hybrid cell lines.

\begin{tabular}{c|r|r|r|r|r|r|r|r|r|r|r}
\hline \multirow{2}{*}{$\begin{array}{c}\text { Hybrid } \\
\text { cell } \\
\text { lines }\end{array}$} & \multicolumn{4}{|c|}{ Enzymes } & \multicolumn{1}{c}{ Chromosomes } \\
\cline { 2 - 11 } & GPI & LDHA & MPI & NP & PEPA & 1 & 2 & 3 & 4 & 5 & 6 \\
\hline 1 & & + & & & & & & & & & \\
2 & + & & + & + & & & & & & & 8.3 \\
3 & & & & & & & & & & & 75.1 \\
4 & & & & & & 33.3 & & 33.3 & & 29.6 & \\
5 & & & + & + & & & & 27.5 & & 2.5 & \\
6 & + & + & + & + & & & & & 61.8 & & \\
7 & & & + & + & & 43.6 & & 34.5 & & & \\
8 & & + & + & + & & & 50.0 & 6.3 & 6.3 & & \\
9 & + & & + & + & & & 2.9 & & 5.7 & & 57.1 \\
10 & + & + & + & + & & & & 15.6 & & 6.3 & 28.1 \\
\hline
\end{tabular}

TABLE 2

The results for the enzymes MPI and NP at a pig chromosome level of 10 p. 100 :

The values of Phi, Chisq, OR and $R_{j}$.

\begin{tabular}{|l|c|c|c|c|c|r|r|r|r|r|}
\hline \hline Chr & $+1+$ & $-/+$ & $+/-$ & $-l-$ & Con & Dis & Phi & Chisq & OR & $\mathrm{R}_{\mathrm{i}}$ \\
\hline & & & & & & & & & & \\
7 & 5 & 0 & 2 & 3 & 8 & 2 & .65 & 4.29 & 12.01 & 27.22 \\
8 & 3 & 0 & 4 & 3 & 6 & 4 & .43 & 1.84 & 7.01 & 3.18 \\
9 & 4 & 1 & 3 & 2 & 6 & 4 & .22 & .48 & 8.74 & 2.43 \\
12 & 5 & 2 & 2 & 1 & 6 & 4 & .05 & .02 & 13.15 & 1.86 \\
6 & 3 & 1 & 4 & 2 & 5 & 5 & .09 & .08 & 8.02 & .83 \\
3 & 3 & 1 & 4 & 2 & 5 & 5 & .09 & .08 & 7.07 & .83 \\
10 & 3 & 1 & 4 & 2 & 5 & 5 & .09 & .08 & 6.92 & .83 \\
2 & 1 & 0 & 6 & 3 & 4 & 6 & .22 & .48 & 11.91 & .37 \\
4 & 1 & 0 & 6 & 3 & 4 & 6 & .22 & .48 & 6.91 & .37 \\
13 & 0 & 0 & 7 & 3 & 3 & 7 & $\mathrm{nc}$ & $\mathrm{nc}$ & 1.91 & .13 \\
14 & 0 & 0 & 7 & 3 & 3 & 7 & $\mathrm{nc}$ & $\mathrm{nc}$ & 1.91 & .13 \\
15 & 0 & 0 & 7 & 3 & 3 & 7 & $\mathrm{nc}$ & $\mathrm{nc}$ & 1.91 & .13 \\
16 & 0 & 0 & 7 & 3 & 3 & 7 & $\mathrm{nc}$ & $\mathrm{nc}$ & 1.91 & .13 \\
17 & 0 & 0 & 7 & 3 & 3 & 7 & $\mathrm{nc}$ & $\mathrm{nc}$ & 1.91 & .13 \\
18 & 0 & 0 & 7 & 3 & 3 & 7 & $\mathrm{nc}$ & $\mathrm{nc}$ & 1.91 & .13 \\
$\mathrm{X}$ & 0 & 0 & 7 & 3 & 3 & 7 & $\mathrm{nc}$ & $\mathrm{nc}$ & 1.91 & .13 \\
1 & 1 & 1 & 6 & 2 & 3 & 7 & -.22 & .48 & 2.57 & .10 \\
5 & 0 & 1 & 7 & 2 & 2 & 8 & -.51 & 2.59 & 1.14 & .03 \\
11 & 0 & 1 & 7 & 2 & 2 & 8 & -.51 & 2.59 & 1.14 & .03 \\
\hline
\end{tabular}

Chr : chromosome ; Con : concordant ; Dis : discordant ; nc : not calculated. 
Our results are not really supported by the statistical procedures proposed by Cowmeadow \& Rudde (1978), as the OR value for chromosome no. 12 is greater than the one for chromosome no. 7. Based on our data the likelihood ratios $R_{j}$ indicate that the assignment of the genes for MPI and NP to the pig chromosome no. 7 is 30 times more likely than the assignment to the chromosome no. 3 . If we go down to a donor chromosome level of 5 p. 100, the procedures by Cowmeadow \& RuddLe (1978) also lead to the assignment of the genes for MPI and NP to the pig chromosome no. 7 (table 3). However, we base our assignment only on the observations at a donor chromosome level of 10 p. 100 since we consider this a reasonable level. Table 3 has been added in order to point out the great influence of the donor chromosome level on the interpretation of the data.

TABLE 3

The results for the enzymes MPI and NP at a pig chromosome level of 5 p. 100 : The values of Phi, Chisq, OR and $R_{j}$.

\begin{tabular}{|l|c|c|c|c|c|c|r|r|r|r|}
\hline \hline Chr & $+/+$ & $-l+$ & $+/-$ & $-l-$ & Con & Dis & Phi & Chisq & OR & $\mathrm{R}_{\mathrm{j}}$ \\
\hline & & & & & & & & & & \\
7 & 6 & 0 & 1 & 3 & 9 & 1 & .80 & 6.43 & 12.68 & 46.13 \\
10 & 5 & 1 & 2 & 2 & 7 & 3 & .36 & 1.27 & 10.85 & 4.12 \\
8 & 3 & 0 & 4 & 3 & 6 & 4 & .43 & 1.84 & 6.75 & 1.84 \\
4 & 3 & 0 & 4 & 3 & 6 & 4 & .43 & 1.84 & 9.25 & 1.84 \\
3 & 4 & 1 & 3 & 2 & 6 & 4 & .22 & .48 & 8.82 & 1.41 \\
9 & 4 & 1 & 3 & 2 & 6 & 4 & .22 & .48 & 7.41 & 1.41 \\
12 & 5 & 2 & 2 & 1 & 6 & 4 & .05 & .02 & 10.65 & 1.08 \\
2 & 1 & 0 & 6 & 3 & 4 & 6 & .22 & .48 & 4.49 & .21 \\
$\mathrm{X}$ & 1 & 0 & 6 & 3 & 4 & 6 & .22 & .48 & 3.42 & .21 \\
6 & 3 & 2 & 4 & 1 & 4 & 6 & -.22 & .48 & 5.86 & .13 \\
13 & 0 & 0 & 7 & 3 & 3 & 7 & $\mathrm{nc}$ & $\mathrm{nc}$ & 1.99 & .07 \\
14 & 0 & 0 & 7 & 3 & 3 & 7 & $\mathrm{nc}$ & $\mathrm{nc}$ & 1.99 & .07 \\
15 & 0 & 0 & 7 & 3 & 3 & 7 & $\mathrm{nc}$ & $\mathrm{nc}$ & 1.99 & .07 \\
16 & 0 & 0 & 7 & 3 & 3 & 7 & $\mathrm{nc}$ & $\mathrm{nc}$ & 1.99 & .07 \\
17 & 0 & 0 & 7 & 3 & 3 & 7 & $\mathrm{nc}$ & $\mathrm{nc}$ & 1.99 & .07 \\
18 & 0 & 0 & 7 & 3 & 3 & 7 & $\mathrm{nc}$ & $\mathrm{nc}$ & 1.99 & .07 \\
1 & 1 & 1 & 6 & 2 & 3 & 7 & -.22 & .48 & 2.65 & .06 \\
5 & 1 & 1 & 6 & 2 & 3 & 7 & -.22 & .48 & 3.22 & .06 \\
11 & 1 & 2 & 6 & 1 & 2 & 8 & -.52 & 2.74 & 1.98 & .01 \\
\hline
\end{tabular}

Chr : chromosome ; Con : concordant ; Dis : discordant ; nc : not calculated.

Four hybrid lines out of 10 showed the pig GPI but not the pig chromosome no. 15. But, as mentioned in the introduction, it is suspected that the linkage group GPI-HAL-S-H-PO2-PGD could be located on chromosome no. 15. We do not worry about this suspicion, because the data it is based on are very weak. For example, FrIES et al. (1982) estimated a recombination frequency between the centromere of chromosome no. 15 and the locus for GPI of $30 \mathrm{p}$. 100 . A similar recombination frequency was found by ANDREsen (1967) between the loci for the $\mathrm{G}$ and the $\mathrm{H}$ blood group. But this kind of data, obtained by family analysis, can only be considered a hint, since the underlying investigations are not designed to detect this kind of genetic distance. The results presented by TikHonov et al. (1983) indicate a close linkage of 3.9 p. 100 between the loci for the $\mathrm{G}$ and the $\mathrm{H}$ blood group. This is somehow in contradiction 
with the findings mentioned above. We think it amazing, that such a close linkage has not yet been confirmed by other researchers, especially since the linkage group GPIHAL-S-H-PO2-PGD has been investigated thoroughly by many researchers. Our results rather indicate that this linkage group is not located on chromosome no. 15.

No attempt was made to map the gene for thymidine kinase (TK). After isolation the clones were kept in normal medium without aminopterine. Therefore we can not exclude the occurrence of revertants or even the loss of the pig chromosome carrying the gene for TK.

Received November 7, 1985.

Accepted June 17, 1986.

\section{Acknowledgements}

We thank Dr. P.L. Pearson and Dr. P. Meera Khan for teaching and advising us in gene mapping with somatic cell hybrids, Mrs. I. Dolf for her technical assistance, Dr. S. BecK for writing the computer program and Dr. H.-R. Roth for elaborating the statistical procedure of the likelihood ratios.

\section{References}

ANDRESEn E., 1967. Sequential analysis of genetic linkage in pigs. Yearbook 1968, Preprint, 1-11, Royal Veterinary and Agricultural College, Copenhagen, Danemark.

BURgerhout W.G., 1978. A standard procedure for gene assignment by use of somatic cell hybrids. Cytogenet. Cell Genet., 22, 689-693.

Caspersson T., Zech L., Modest E.J., Foley G.E., Wagh U., Simonsson E., 1969. Chemical differentiation with fluorescent alkylating agents in Vicia faba metaphase chromosomes. Exptl Cell Res., 58, 128-140.

Christensen K., Kaufmann U., Avery B., 1985. Chromosome mapping in domestic pigs (Sus scrofa), MPI and NP located to chromosome 7. Hereditas, 102, 231-236.

Cowmeadow M.P., Ruddle F.H., 1978. Computer-assisted statistical procedures for somatic cell gene assignment. Cytogenet. Cell Genet., 22, 694-697.

Dolf G., 1984. Genkartierung beim Schwein mit Hilfe von somatischen Zellhybriden. Dissertation ETH 7644.

Dolf G., Stranzinger G., 1982. An approach to gene mapping in swine by use of cell hybridization techniques. 5th Eur. Colloq. Cytogenet. Domest. Anim., Milano-Gargnano, Italy, June 7-11, 1982, Succi G., De Giovanni Macchi A., Molteni L. (eds.), 222-224, Ricerca scientifica et educazione permanente, Supplemento n. 24.

Echard G., Gellin J., Benne F., Gillois M., 1982. Progress in gene mapping of rabbits, cattle and pigs using somatic cell hybridization. 5th Eur. Colloq. Cytogenet. Domest. Anim., MilanoGargnano, Italy, June 7-11, 1982, Succi G., De Giovanni Macchi A., Molteni L. (eds.), 237-252, Ricerca scientifica et educazione permanente, Supplemento n. 24.

Echard G., Geluin J., Gillois M., 1984. Localisation des gènes MPI, PKM2, NP sur le chromosome 3 du porc (Sus scrofa $L$.) et analyse cytogénétique d'une lignée de hamster chinois issue de la DON (wg3h). Génét. Sél. Evol., 16, 261-270.

Echard G., Yerle M., Gellin J., Dalens M., Gillois M., 1986. Assignment of the major histocompatibility complex to the p $1.4 \rightarrow$ q1.2 region of chromosome 7 in the pig (Sus scrofa domestica L.) by in situ hybridisation. Cytogenet. Cell Genet., 41, 126-128.

Foerster M., Hecht W., 1984. Some provisional gene assignments in pig. 6th Eur. Colloq. Cytogenet. Domest. Anim., Zurich, Switzerland, July 16-20, 1984, Stranzinger G. (ed.), 351352, Institute of Animal Production, Animal Breeding Section, Federal Institute of Technology (ETH), Zurich, Switzerland. 
Foerster M., Stranzinger G., Hellkuhl B., 1980. X-chromosome gene assignment of swine and cattle. Naturwissenschaften, 67, 48.

FrIES H.-R., 1982. Natürliche und induzierte Markerchromosomen beim Schwein und ihre Verwendung für die Genkartierung. Dissertation ETH, $\mathbf{7 1 6 0}$.

Fries R., Dolf G., Stranzinger G., 1982. Genkartierung bei landwirtschaftlichen Nutztieren : Gegenwärtiger Stand, eigene Untersuchungen und Anwendungsmöglichkeiten. Schweiz. Landw. Monatshefte, Sondernummer, 205-221.

Fries R., Rasmusen B.A., Jarrell V.L., Maurer R.R., 1984. Confirmation of the provisional assignment of the G-blood group locus to chromosome 15 in swine. 6th Eur. Colloq. Cytogenet. Domest. Anim., Zurich, Switzerland, July 16-20, 1984, Stranzinger G. (ed.), 358367, Institute of Animal Production, Animal Breeding Section, Federal Institute of Technology (ETH), Zurich, Switzerland.

Gefrrotin C., Popescu C.P., Cribiu E.P., Boscher J., Renard Ch., Chardon P., Vaiman M., 1984. Assignment of MHC in swine to chromosome 7 by in situ hybridization and serological typing. Ann. Génét., 27, 213-219.

Gellin J., Benne F., Hors-Cayla M.C., Gillois M., 1980. Carte génique du porc (Sus scrofa L.). I. Etude de deux groupes synténiques G6PD, PGK, HPRT et PKM2, MPI. Ann. Génét., 23, 15-21.

Gellin J., Echard G., Benne F., Gillois M., 1981. Pig gene mapping : PKM2 MPI-NP synteny. Cytogenet. Cell Genet., 30, 59-62.

Harding J.D.J., Done J.T., Harbourne J.F., Randall C.J., Gilbert F.R., 1973. Congenital tremor type AIII in pigs : a hereditary sex-linked cerebrospinal hypomyelinogenesis. Vet. Rec., 92, 527-529.

Hruban V., Simon M., Hradecky J., Jilek F., 1976. Linkage of the pig main histocompatibility complex and the $\mathrm{J}$ blood group system. Tissue Antigens, 7, 267-271.

LAX T., 1971. Hereditary splayleg in pigs. J. Hered., 62, 250-251.

Leong M.M.L., Lin C.C., Ruth R.F., 1983a. The localization of genes for HPRT, G6PD and aGAL onto the X-chromosome of domestic pig (Sus scrofa domesticus). Can. J. Genet. Cytol., 25, 239-245.

LEONG M.M.L., LiN C.C., Ruth R.F., 1983b. Assignment of superoxide dismutase (SOD-1) gene to chromosome no. 9 of domestic pig. Can. J. Genet. Cytol., 25, 233-238.

Meera Khan P., 1971. Enzyme electrophoresis on cellulose acetate gel : Zymogram patterns in man-mouse and man-Chinese hamster somatic cell hybrids. Arch. Biochem. Biophys., 145, 470-483.

Muir W.M., RASmuSEn B.A., 1974. A combined estimate of recombination between the genes for $\mathrm{C}$ and $\mathrm{J}$ blood groups in pigs. Anim. Blood Grps biochem. Genet., 5, 133-135.

Rabin M., Fries R., Singer D., Ruddle F.H., 1985. Assignment of the porcine major histocompatibility complex to chromosome 7 by in situ hybridization. Cytogenet. Cell Genet., 39, 206209.

Ray M., Mohandas T., 1976. Proposed banding nomenclature for the Chinese hamster chromosomes (Cricetulus griseus). Cytogenet. Cell Genet., 16, 83-91.

Reading Conference 1976, 1980. Proceedings of the first international conference for the standardisation of banded karyotypes of domestic animals. Hereditas, 92, 145-162.

Tiknonov V.N., Nikitin S.V., 1983. Mapping of the locus for the G blood group system on an identified chromosome of domestic and wild pigs. Dokl. Akad. Nauk SSSR, 272, 214-216.

Tikhonov V.N., Gorelov I.G., Nikitin S.V., Bobovich V.E., Astakhova N.M., 1983. Mapping of the locus for the $\mathrm{H}$ blood group system on chromosome 15 of domestic pigs. Dokl. Akad. Nauk SSSR, 272, 486-489.

Van Someren H., Beijersbergen Van Henegouwen H., Los W., Wurzer-Figurelli E., Doppert B., Vervloet M., Meera Khan P., 1974. Enzyme electrophoresis on cellulose acetate gel. II. Zymogram patterns in man-Chinese hamster somatic cell hybrids. Humangenetik, 25, 189201.

Westerveld A., Visser R.P.L.S., Meera Khan P., Bootsma D., 1971. Loss of human genetic markers in man-Chinese hamster somatic cell hybrids. Nature New Biology, 234, 20-24. 